\title{
Map of the Book
}

\begin{tabular}{|c|c|c|c|c|c|c|c|}
\hline $\begin{array}{l}\text { Module and } \\
\text { Topic }\end{array}$ & Reading & Grammar & Vocabulary & Listening & Translation & Writing & Speaking \\
\hline $\begin{array}{l}\text { Module } 1 \\
\text { Culture and } \\
\text { Society }\end{array}$ & $\begin{array}{l}\text { Reading } \\
\text { about and } \\
\text { understanding } \\
\text { the culture and } \\
\text { society of the } \\
\text { Middle East. } \\
\text { Comprehension } \\
\text { questions. }\end{array}$ & 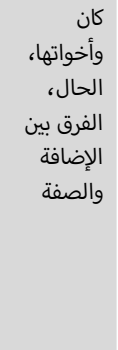 & $\begin{array}{l}\text { Vocabulary to } \\
\text { describe and } \\
\text { discuss places } \\
\text { and cultures. }\end{array}$ & $\begin{array}{l}\text { Listening to } \\
\text { a text on a } \\
\text { country in the } \\
\text { Middle East. } \\
\text { Drills, including } \\
\text { comprehension } \\
\text { and language in } \\
\text { context. }\end{array}$ & $\begin{array}{l}\text { Translation } \\
\text { of sentences, } \\
\text { paragraphs and } \\
\text { texts from and } \\
\text { into English. } \\
\text { Vocabulary on } \\
\text { places in the } \\
\text { Middle East, } \\
\text { and its use in } \\
\text { context. }\end{array}$ & $\begin{array}{l}\text { Locating and } \\
\text { correcting } \\
\text { errors in a } \\
\text { text. Thinking } \\
\text { and writing } \\
\text { in Arabic; } \\
\text { avoiding } \\
\text { writing in } \\
\text { Arabic through } \\
\text { translation. }\end{array}$ & $\begin{array}{l}\text { Discussing } \\
\text { places to } \\
\text { visit in the } \\
\text { Middle East. }\end{array}$ \\
\hline $\begin{array}{l}\text { Module } 2 \\
\text { The } \\
\text { Environment }\end{array}$ & $\begin{array}{l}\text { Reading } \\
\text { texts on the } \\
\text { environment } \\
\text { and how to } \\
\text { protect it. A } \\
\text { glossary and } \\
\text { drills. }\end{array}$ & 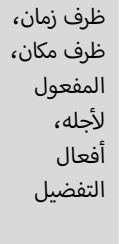 & $\begin{array}{l}\text { Learning } \\
\text { terminology } \\
\text { specific to the } \\
\text { environment } \\
\text { and its use in } \\
\text { the context. }\end{array}$ & $\begin{array}{l}\text { Listening to two } \\
\text { passages on } \\
\text { volcanos. }\end{array}$ & $\begin{array}{l}\text { Translation } \\
\text { of texts and } \\
\text { sentences } \\
\text { related to } \\
\text { environmental } \\
\text { issues }\end{array}$ & $\begin{array}{l}\text { Learning } \\
\text { vocabulary and } \\
\text { writing short } \\
\text { paragraphs } \\
\text { on the } \\
\text { environment. }\end{array}$ & $\begin{array}{l}\text { Discussing } \\
\text { what nature } \\
\text { holds in } \\
\text { store for us } \\
\text { and ways of } \\
\text { coping. }\end{array}$ \\
\hline $\begin{array}{l}\text { Module } 3 \\
\text { Education }\end{array}$ & $\begin{array}{l}\text { Reading and } \\
\text { understanding } \\
\text { texts about } \\
\text { education. } \\
\text { Drills, } \\
\text { comprehension } \\
\text { questions } \\
\text { and language } \\
\text { in context } \\
\text { exercises. }\end{array}$ & $\begin{array}{r}\text { أن أخواتها، } \\
\text { المفعولق }\end{array}$ & $\begin{array}{l}\text { Words, phrases } \\
\text { and idiomatic } \\
\text { expressions } \\
\text { about different } \\
\text { aspects of } \\
\text { education. }\end{array}$ & $\begin{array}{l}\text { Listening } \\
\text { to a text on } \\
\text { the future of } \\
\text { education in } \\
\text { a changing } \\
\text { world. Drills, } \\
\text { comprehension } \\
\text { questions and } \\
\text { language in } \\
\text { context drills. }\end{array}$ & $\begin{array}{l}\text { Translating } \\
\text { sentences, } \\
\text { paragraphs and } \\
\text { texts about } \\
\text { education, } \\
\text { from and } \\
\text { into English. } \\
\text { Learning and } \\
\text { using key } \\
\text { translated } \\
\text { concepts and } \\
\text { expressions in } \\
\text { the glossary. }\end{array}$ & $\begin{array}{l}\text { Writing } \\
\text { cohesive } \\
\text { paragraphs, } \\
\text { essays and } \\
\text { letters; } \\
\text { summarising } \\
\text { texts. }\end{array}$ & $\begin{array}{l}\text { Using } \\
\text { expressions } \\
\text { of opinion } \\
\text { to discuss } \\
\text { issues } \\
\text { related to } \\
\text { education } \\
\text { in the Arab } \\
\text { World. }\end{array}$ \\
\hline $\begin{array}{l}\text { Module } 4 \\
\text { Global Issues }\end{array}$ & $\begin{array}{l}\text { Reading } \\
\text { about and } \\
\text { understanding } \\
\text { the state of } \\
\text { science and } \\
\text { technology in } \\
\text { the Arab World. }\end{array}$ & الأسماء، الإسماءة، & $\begin{array}{l}\text { Learning } \\
\text { terminology } \\
\text { specific to } \\
\text { international } \\
\text { issues. }\end{array}$ & $\begin{array}{l}\text { Listening to } \\
\text { passages on } \\
\text { the Arab Spring } \\
\text { and the future } \\
\text { of economic } \\
\text { resources in the } \\
\text { region. }\end{array}$ & $\begin{array}{l}\text { Translating } \\
\text { texts related to } \\
\text { current issues }\end{array}$ & $\begin{array}{l}\text { Listening to } \\
\text { texts about the } \\
\text { Arab Spring } \\
\text { and the future } \\
\text { of economic } \\
\text { resources. }\end{array}$ & $\begin{array}{l}\text { Discussing } \\
\text { global } \\
\text { issues, and } \\
\text { expressing } \\
\text { opinions. }\end{array}$ \\
\hline $\begin{array}{l}\text { Module } 5 \\
\text { Media and } \\
\text { Communication }\end{array}$ & $\begin{array}{l}\text { Reading and } \\
\text { understanding } \\
\text { texts about } \\
\text { media and } \\
\text { communication. } \\
\text { Glossaries and } \\
\text { comprehension } \\
\text { questions. }\end{array}$ & الصرف المموع من & $\begin{array}{l}\text { Vocabulary } \\
\text { in context; } \\
\text { learning new } \\
\text { phrases and } \\
\text { synonyms; key } \\
\text { terminologies } \\
\text { about } \\
\text { media and } \\
\text { communication. }\end{array}$ & $\begin{array}{l}\text { Listening to } \\
\text { texts and } \\
\text { answering } \\
\text { questions about } \\
\text { media and } \\
\text { communication. }\end{array}$ & $\begin{array}{l}\text { Translating } \\
\text { sentences and } \\
\text { paragraphs } \\
\text { about } \\
\text { media and } \\
\text { communication } \\
\text { into Arabic. } \\
\text { Translation of } \\
\text { a text about } \\
\text { impartiality } \\
\text { of media into } \\
\text { English. }\end{array}$ & $\begin{array}{l}\text { Writing } \\
\text { personal } \\
\text { letters; using } \\
\text { connectors to } \\
\text { write essays } \\
\text { on media- } \\
\text { related topics; } \\
\text { phrases and } \\
\text { expressions } \\
\text { for writing } \\
\text { introductions } \\
\text { and } \\
\text { conclusions. }\end{array}$ & $\begin{array}{l}\text { Using } \\
\text { expressions } \\
\text { of insistence } \\
\text { to discuss } \\
\text { social } \\
\text { media; } \\
\text { expressions } \\
\text { and phrases } \\
\text { relating to } \\
\text { the pros } \\
\text { and cons } \\
\text { of social } \\
\text { media. }\end{array}$ \\
\hline
\end{tabular}




\begin{tabular}{|c|c|c|c|c|c|c|c|}
\hline $\begin{array}{l}\text { Module } 6 \\
\text { Economy and } \\
\text { Development }\end{array}$ & $\begin{array}{l}\text { Reading and } \\
\text { comprehending } \\
\text { texts about } \\
\text { the economy. } \\
\text { Comprehension } \\
\text { and language } \\
\text { in context } \\
\text { questions. }\end{array}$ & الأسماء المضة، المبني & $\begin{array}{l}\text { Learning new } \\
\text { vocabulary on } \\
\text { the economy. }\end{array}$ & $\begin{array}{l}\text { Listening to } \\
\text { a text } \\
\text { on Arab } \\
\text { revolutions and } \\
\text { their knock-on } \\
\text { effect on the } \\
\text { economy. } \\
\text { Comprehension } \\
\text { questions. }\end{array}$ & $\begin{array}{l}\text { Translating } \\
\text { paragraphs, } \\
\text { texts and } \\
\text { expressions } \\
\text { about the } \\
\text { economy into } \\
\text { English. }\end{array}$ & $\begin{array}{l}\text { Using } \\
\text { expressions } \\
\text { pertaining to } \\
\text { expenditure in } \\
\text { context; using } \\
\text { expressions of } \\
\text { causality and } \\
\text { effect to write } \\
\text { an essay about } \\
\text { unemployment. }\end{array}$ & $\begin{array}{l}\text { Using } \\
\text { expressions } \\
\text { to discuss } \\
\text { topics } \\
\text { related } \\
\text { to the } \\
\text { economy. }\end{array}$ \\
\hline $\begin{array}{l}\text { Module } 7 \\
\text { Sports }\end{array}$ & $\begin{array}{l}\text { Reading texts } \\
\text { about sports. } \\
\text { Answering } \\
\text { comprehension } \\
\text { questions. }\end{array}$ & الماضي المجهول، المضارع & $\begin{array}{l}\text { Learning } \\
\text { and using } \\
\text { vocabulary } \\
\text { about sports. }\end{array}$ & $\begin{array}{l}\text { Listening to } \\
\text { texts } \\
\text { about sports } \\
\text { and tourism. A } \\
\text { glossary and } \\
\text { drills. }\end{array}$ & $\begin{array}{l}\text { Translating } \\
\text { texts about } \\
\text { sports from and } \\
\text { into Arabic. }\end{array}$ & $\begin{array}{l}\text { Using } \\
\text { expressions of } \\
\text { preference to } \\
\text { write about } \\
\text { sports. Using } \\
\text { expressions } \\
\text { related to } \\
\text { success and } \\
\text { failure. }\end{array}$ & $\begin{array}{l}\text { Discussing } \\
\text { different } \\
\text { aspects } \\
\text { of sports, } \\
\text { including } \\
\text { the impact } \\
\text { of sports on } \\
\text { health and } \\
\text { the pros of } \\
\text { sports. }\end{array}$ \\
\hline $\begin{array}{l}\text { Module } 8 \\
\text { Arts and } \\
\text { Literature }\end{array}$ & $\begin{array}{l}\text { Reading texts } \\
\text { about Arabic } \\
\text { literature. } \\
\text { Answering } \\
\text { comprehension } \\
\text { questions. }\end{array}$ & للا للانسية المنس، المفعول & $\begin{array}{l}\text { Learning and } \\
\text { using words, } \\
\text { phrases } \\
\text { and literary } \\
\text { expressions. }\end{array}$ & $\begin{array}{l}\text { Listening to } \\
\text { texts } \\
\text { about Arabic } \\
\text { literature. A } \\
\text { glossary and } \\
\text { drills. }\end{array}$ & $\begin{array}{l}\text { Translation of } \\
\text { literary texts } \\
\text { into English. }\end{array}$ & $\begin{array}{l}\text { Using } \\
\text { expressions } \\
\text { of preference } \\
\text { to write } \\
\text { about Arabic } \\
\text { literature. } \\
\text { Learning about } \\
\text { literature and } \\
\text { prominent Arab }\end{array}$ & $\begin{array}{l}\text { Discussing } \\
\text { Arabic } \\
\text { literature } \\
\text { and writers, } \\
\text { and other } \\
\text { related } \\
\text { topics. }\end{array}$ \\
\hline
\end{tabular}

\section{Key to Symbols}

\section{A/Z Glossary \\ ? Comprehension questions}

(o) Language in context

Translation
Listening

Answer key

6699 Speaking

G Grammar

at Writing 